\title{
SIMKANIA NEGEVENSIS: IS IT A REAL RESPIRATORY PATHOGEN?
}

\author{
MeHmet Kose ${ }^{1 *}$, DuYGU EKInCI ${ }^{1}$, Selma GoKAHMETOGLU², \\ TUBA ELMAS ${ }^{1}$ and MUSTAFA KÜRŞAD ÖZTÜRK ${ }^{3}$ \\ ${ }^{1}$ Department of Pediatrics, Division of Pediatric Pulmonology Unit, Erciyes University, \\ Kayseri, Turkey \\ ${ }^{2}$ Department of Microbiology, Erciyes University, Kayseri, Turkey \\ ${ }^{3}$ Department of Pediatrics, Division of Pediatric Infectious Diseases, Erciyes University, \\ Kayseri, Turkey
}

(Received: 27 November 2014; accepted: 3 March 2015)

\begin{abstract}
Simkania negevensis, a recently discovered Chlamydia-like organism, has been associated with respiratory infections such as pneumonia, bronchiolitis and chronic obstructive pulmonary disease in children and adults. The aim of the present study was to evaluate $S$. negevensis in the etiology of pediatric community-acquired pneumonia, bronchiolitis and asthma exacerbation in our region. Overall, 102 patients and 46 healthy controls were included in the study. S. negevensis was investigated by real time PCR (Primer Design, UK) in nasopharyngeal swab samples. It failed to be detected in either the study or control group. In conclusion, our results suggest that $S$. negevensis is not an important respiratory pathogen in our region.
\end{abstract}

Keywords: Simkania negevensis in Turkey, pediatric pneumonia, bronchiolitis, exacerbation of asthma

\section{Introduction}

Simkania negevensis was first defined in 1993 [1]. S. negevensis, is an obligate intracellular microorganism that is similar to Chlamydia. It has been recommended that $S$. negevensis, formerly called "Z" or "Simkania Z", be named as a new family under Simkaniacea. Along with the globally varying seroprevalence of $S$. negevensis, there exists a high rate of seropositivity for some populations and it is associated with various respiratory diseases [2]. S. negevensis has been proven to have an association with acute bronchiolitis [3], community-acquired

\footnotetext{
* Corresponding author; E-mail: mhmtkose@yahoo.com
} 
pneumonia in adults [4] and acute exacerbation of chronic obstructive pulmonary disease (COPD) [5]. It is not known to be existent in Turkey.

The aim of this study was to explore the existence of $S$. negevensis as an etiologic agent for children applying with acute bronchiolitis, communityacquired pneumonia and acute exacerbation of asthma.

\section{Materials and Methods}

The study was conducted prospectively from February 2012 to April 2013 in Erciyes University Faculty of Medicine Children's Health and Diseases Department. One hundred and two in the age range of 1 month-10 years with diagnosed pneumonia, bronchiolitis and exacerbation of asthma who were being medically treated at the polyclinics and services of Erciyes University Faculty of Medicine Children's Health and Diseases Department were involved in the study. Additionally, a control group consisting of 46 healthy children was formed. The children were classified into 4 groups according to the complaint at the time of application, evidences of the physical consultation and posterior-anterior lung graphy. Group 1: Pneumonia group: Patients applying with cough or respiratory problem according to WHO, with their age taken into consideration, having tachypnoea or retraction without wheezing and having abnormal results on lung graphy were regarded as belonging to the Pneumonia group. Group 2: Bronchiolitis Group: The clinical state of children under the age of 3 characterized by wheezing, tachypnoea and retractions was regarded as Bronchiolitis. Group 3: Exacerbation of Asthma Group: This group was formed of patients who had been previously diagnosed as having asthma and came with exacerbations during treatment. Group 4: Control Group: Children without respiratory problems who were totally healthy. Patients with a story of antibiotic usage during the last 72 hours, who had been medicated while staying in hospital during the last 15 days and who had latent chronic diseases were not involved in the study.

Nasopharyngeal swab specimens which were taken with a sterile throat culture swab were placed into an eppendorf tube and $1.5 \mathrm{ml}$ of PBS (Phosphate Buffer Solution) was added. After being closed, the tube was kept at a temperature of $-80{ }^{\circ} \mathrm{C}$ until the examination date of the specimens.

Nucleic acid isolation for all of the specimens was made using a QIA symphony DSP Virus/Pathogen Midi Kit Version 1 (Qiagen, Germany), in accordance with the kit procedure. During nucleic acid isolation procedure internal control (plasmid DNA) for control of PCR inhibition was added to each tube. For genome quantification of $S$. negevensis a real time PCR kit (Primer Design, UK) was used [6]. The primers of kit amplified $117 \mathrm{bp}$ fragment of the $16 \mathrm{~S}$ and $23 \mathrm{~S}$ 
ribosomal RNA of $S$. negevensis. Positive control (plasmid DNA) and negative control were also studied. For all of the specimens and the controls the PCR process was conducted with a Rotor-Gene Q5 plex device (Qiagen, Germany) for the detection of genome.

\section{Results}

Out of the 102 cases involved in the patient group, 45 (44\%) belonged to the Pneumonia group, 32 (31\%) belonged to the Acute Bronchiolitis group and 25 (25\%) belonged to the Exacerbation of Asthma group. Out of the 45 patients in the Pneumonia group 19 (42.2\%) were girls and 26 (57.8\%) were boys. Out of the 32 patients in the Acute Bronchiolitis group 15 (46.9\%) were girls and 17 (53.1\%) were boys. Out of the 25 patients in the Exacerbation of Asthma group $11(44 \%)$ were girls and 14 (56\%) were boys. The average age of the Pneumonia group was 46 months $( \pm 38)$, the average age of the Bronchiolitis group was 14 months $( \pm 11)$ and the average age of the Exacerbation of Asthma group was 55 months $( \pm 32)$. The average age of all of the patient groups was $38 \pm 35$ months and that of the control group was $39 \pm 31$ months. $S$. negevensis could not be diagnosed with PCR in either the patient groups or the control group. Amplification of the positive control was good. Amplification of the internal controls was checked and all of them were amplified. Then there was no PCR inhibition in the specimens.

\section{Discussion}

Simkania negevensis has been identified as an effective agent in children and adults in both the healthy population and in sufferers of respiratory problems. The seropositivity of $S$. negevensis in the healthy population in Israel, the United Kingdom and Denmark has been determined to be \%46-80 [6-8].

In a study by Kahane et al. [3] conducted in Israel, using culture and/or the PCR method, S. negevensis was researched in specimens of nasopharyngeal wash taken from 120 infants with bronchiolitis with an age range of 2 weeks to 12 months. The positivity rate of $S$. negevensis was calculated to be $28 \%$ while $S$. negevensis could not be detected in the control group consisting of 56 people and a statistically significant difference was found when the two groups were compared [3]. Greenberg et al. [9] reported that they identified a positivity rate of $64 \%$ for $S$. negevensis with the PCR method on the specimens taken from 22 infants with bronchiolitis in Canada [9]. In a study conducted by Kumar et al. [2] in Brooklyn, NY, S. negevensis was researched in a group of patients consisting 
of 188 children and adults (aged between 2 weeks -83 years) diagnosed with asthma, bronchiolitis and pneumonia. A control group of 110 healthy subjects who were of similar age was also included. It was reported that $S$. negevensis was detected in $17 \%$ of the patients and $23 \%$ of the control group in the nasopharyngeal swab material with the PCR method [2]. In a study by Korppi et al. [10], which was conducted in Finland, they searched for $S$. negevensis in a group of 104 patients with recent diagnosis of asthma who were aged between 1-6 years. A control group of 120 subjects was also included. $\operatorname{IgG}, \operatorname{IgA}$ and $\operatorname{IgM}$ were searched in the blood specimens with microimmunofluorescence (MIF) test. $S$. negevensis was found to be positive at a rate of $16 \%$. S. negevensis was proven to cause infection in pre-school children but no correlation with asthma was detected [10]. In a recent study, S. negevensis was investigated with the PCR method in the bronchoalveolar lavage fluids of 41 lung transplantation patients. Surprisingly positivity was detected in 40 of them and this situation was shown to be associated with acute rejection [11]. In a recent study in Israel, S. negevensis was detected with the PCR in $91 \%$ of 34 children with pneumonia. The researchers detected $S$. negevensis in $88 \%$ of the drinking water specimens taken from the houses of these children leading them to assert that this microorganism was widespread in the environment of the children and that the contamination might have occurred from drinking water [12]. In our study, nasopharyngeal swab specimens were taken from a patients group of 102 subjects out of which 45 had pneumonia, 32 had acute bronchiolitis and 25 had exacerbation of asthma and from a control group of 46 healthy people. S. negevensis was searched for using the PCR method. It was detected neither in the patient groups nor in the control group. The findings of this study contradict those of the above-mentioned studies.

Simkania negevensis has been reported to be frequently seen in Israel, North America and Western Europe, whereas no regional limitation has been made [3, 6-8]. For instance, in a study by Yamaguchi et al. [13] conducted in Japan in a group of 588 healthy people, $S$. negevensis specific IgG was searched for with the MIF technique and a positivity rate of $4.3 \%$ was found in healthy volunteers. For this study group, in only 3 (1\%) of 296 people younger than 19 years of age was positivity detected and $S$. negevensis frequency was found to increase with older age [13]. In the study by Nascimento-Carvalho et al. [14] which was conducted in Brazil, they detected $S$. negevensis as serologically positive (IgG and IgM) in only $3(1.6 \%)$ of 184 children under 5 years of age who were all being treated in hospital for community acquired pneumonia [14]. Consequently, the above-mentioned researchers showed that $S$. negevensis is a real but also a rare cause of lower respiratory tract infection in their regions. They re- 
ported that this situation was due to the variations in the global seroprevalence of $S$. negevensis [13, 14]. In our study, S. negevensis could not be detected either in the patients group or in the control group. Our findings support the variations in the geographic distribution of S. negevensis.

Some limitations are found in this trial. First, the number of children in the study group was limited. Secondly, we only use PCR method because there is no commercial kit for detecting $S$. negevensis autoantibodies worldwide.

Consequently, $S$. negevensis, which has been recently defined and whose prevalence worldwide varies from country to country or amongst age groups, was not detected in the study conducted in our region. This situation led us to the opinion that even if $S$. negevensis exists in our region, it is an extremely rare agent in lower respiratory tract infections. In future studies, the real incidence of S. negevensis can be detected worldwide.

\section{Acknowledgements}

This study was approved by the Ethics Board of Erciyes University (decree number 2011-106 dated 06.12.2011 ) and supported by the Erciyes University Scientific Research Project Fund (Project Number: TTU-2013-4362).

\section{Conflict of Interest}

The authors do not have any conflict of interest.

\section{References}

1. Kahane, S., Gonen, R., Sayada, C., Elion, J., Friedman, M.G.: Description and partial characterization of a new Chlamydia-like microorganism. FEMS Microbiol Lett 109, 329-334 (1993).

2. Kumar, S., Kohlhoff, S.A., Gelling, M., Roblin, P.M., Kutlin, A., Kahane, S., Friedman, M.G., Hammerschlag, M.R.: Infection with Simkania negevensis in Brooklyn, New York. Pediatr Infect Dis J 24, 989-992 (2005).

3. Kahane, S., Greenberg, D., Friedman, M.G., Haikin, H., Dagan, R.: High prevalence of 'Simkania Z', a novel Chlamydia-like bacterium, in infants with acute bronchiolitis. J Infect Dis 177, 1425-1429 (1998).

4. Lieberman, D., Kahane, S., Lieberman, D., Friedman, M.G.: Pneumonia with serological evidence of acute infection with the Chlamydia-like Microorganism ' $Z$ '. J Resp Crit Care Med (Am) 156, 578-582 (1997). 
5. Lieberman, D., Dvoskin, B., Lieberman, D.V., Kahane, S., Friedman, M.G.: Serological evidence of acute infection with the chlamydia-like microorganism Simkania negevensis (z) in acute exacerbation of chronic obstructive pulmonary disease. J Clin Microbiol Infect Dis 21, 307-309 (2002).

6. Johnsen, S., Birkebaek, N., Andersen, P.L., Emil, C., Jensen, J., Ostergaard, L.: Indirect immunofluorescence and real time PCR for detection of Simkania negevensis infection in Danish adults with persistent cough and in healthy controls. Scand J Infect Dis 37, 251-255 (2005)

7. Friedman, M.G., Galil, A., Greenberg, S., Kahane, S.: Seroprevalence of IgG antibodies to the Chlamydia-like microorganism 'Simkania Z' by ELISA. Epidemiol Infect 122, 117-123 (1999).

8. Friedman, M., Kahane, S., Dvoskin, B., Hartley, J.: Detection of Simkania negevensis by culture, PCR, and serology in respiratory tract infection in Cornwall, UK. J Clin Pathol 59, 331-333 (2006).

9. Greenberg, D., Banerji, A., Friedman, M.G., Chiu, C.H., Kahane, S.: High rate of Simkania negevensis among Canadian inuit infants hospitalized with lower respiratory tract infections. Scand J Infect Dis 35, 506-508 (2003).

10. Korppi, M., Paldanius, M., Hyvärinen, A., Nevalainen, A.: Simkania negevensis and newly diagnosed asthma: a case-control study in 1- to 6-year-old children. Respirology 11, 80-83 (2006).

11. Husain, S., Kahane, S., Friedman, M.G., Paterson, D.L., Studer, S., McCurry, K.R., Wolf, D.G., Zeevi, A., Pilewski, J., Greenberg, D.: Simkania negevensis in bronchoalveolar lavage of lung transplant recipients: a possible association with acute rejection. Transplantation 83, 138-143 (2007).

12. Kahane, S., Greenberg, D., Newman, N., Dvoskin, B., Friedman, M.G.: Domestic water supplies as a possible source of infection with Simkania. J Infect 54, 75-81 (2007).

13. Yamaguchi, T., Yamazaki, T., Inoue, M., Mashida, C., Kawagoe, K., Ogawa, M., Shiga, S., Nakagawa, Y., Kishimoto, T., Kurane, I., Ouchi, K., Ohzeki, T.: Prevalences of antibodies against Simkania negevensis in a healthy Japanese population determined by the microimmunofluorescence test. Fems Immunol Med Microbiol 43, 21-27 (2005).

14. Nascimento-Carvalho, C.M., Cardoso, M.R., Paldanius, M., Barral, A., Araújo-Neto, C.A., Saukkoriipi, A., Vainionpää, R., Leinonen, M., Ruuskanen, O.: Simkania negevensis infection among Brazilian children hospitalized with community-acquired pneumonia. J Infect 58, 250-253 (2009). 